\title{
Heat-Resistant Ceramic Pigments on the Base of Waste Vanadium Catalyst and Alumina
}

\author{
M. B. Sedelnikova, N. V. Liseenko, Y. I. Pautova, and V. M. Pogrebenkov \\ Department of Silicate Technology and Nanomaterials, Tomsk Polytechnic University, 30 Lenin Avenue, Tomsk 634050, Russia \\ Correspondence should be addressed to M. B. Sedelnikova; smasha5@yandex.ru
}

Received 17 December 2012; Revised 13 March 2013; Accepted 17 March 2013

Academic Editor: Brajesh Dubey

Copyright ( 2013 M. B. Sedelnikova et al. This is an open access article distributed under the Creative Commons Attribution License, which permits unrestricted use, distribution, and reproduction in any medium, provided the original work is properly cited.

Ceramic pigments on the base of technogenic silica-containing material-waste vanadium catalyst were obtained in this work. Corundum is identified along with the predominant mullite phase in the composition of pigments. The ions of nickel, chromium, and iron are embedded in the structure if the concentration of the corresponding oxide in the initial mixture does not exceed $10 \mathrm{wt} . \%$. In this case, the oxide is not identified in a free form according to the results of X-ray diffraction analysis. $\mathrm{Spinel} \mathrm{CoAl}_{2} \mathrm{O}_{4}$ is formed in cobalt pigments. The developed pigments keep the firing temperature up to $1200^{\circ} \mathrm{C}$. The obtained pigments may be recommended for ceramic paints and colored glazes for building materials.

\section{Introduction}

At the present, the construction industry needs decorative building materials, which are produced with the applying of ceramic pigments, dyes, and decorative glaze. There has been a great interest within the ceramic industry in the development of high-stability pigments, which show intense tonality and satisfy both technological and environmental requirements [1]. While the first step in pigment production involves the judicious choice of raw materials, current trends are towards alternative and less expensive raw materials [2-4]. Normally, the materials of a high chemical purity are used for pigment production. Selected industrial wastes have been investigated for this purpose and, in particular, metal-rich sludges [5-8]. Indeed, industrial processes such as galvanizing or surface coating consume large amounts of water, yielding high volumes of sludge, which requires both environmental and economic treatments [7]. Black ceramic pigments were prepared from $\mathrm{Cr} / \mathrm{Ni}$-rich sludge generated from $\mathrm{Cr} / \mathrm{Ni}$ plating and $\mathrm{Fe}$-rich galvanizing sludge generated during steel wiredrawing [9]. In another work, chroma-tin red malayaite $\mathrm{Ca}(\mathrm{Cr}, \mathrm{Sn}) \mathrm{SiO}_{5}$ pigment was synthesized using $\mathrm{Cr} / \mathrm{Ni}$ plating sludge [10]. The ceramic pigments with wollastonite and diopside structures were produced using nepheline sludge [11].
The requirements to raw materials for ceramic pigment production are constant chemical composition, purity (no coloring impurities), and the ability to form stable crystalline structure. Ceramic pigments with the structure of the potassium feldspar were obtained in [12] with the use of a waste vanadium catalyst. The drawback of these pigments is low synthesis temperature $800-950^{\circ} \mathrm{C}$ and limited application: in overglaze ceramic dyes and for coloring of easily fusible glazes. Ceramic pigments with the mullite structure are characterized by high fire resistance and can be used for both overglaze and underglaze dyes.

The crystal structure of mullite $\left(3 \mathrm{Al}_{2} \mathrm{O}_{3} \cdot 2 \mathrm{SiO}_{2}\right)$ is similar to the sillimanite one, despite some differences in their compositions. A characteristic feature of the mullite structure is the presence of two types of the $\mathrm{Al}^{3+}$ ions; a half of them enter into the crystal lattice with the coordination number 6 , the other half with the coordination number 4 [13]. The pigments with the mullite structure are widespread and well known. They are synthesized from pure chemical agents at $1200-1300^{\circ} \mathrm{C}[14]$.

The purpose of this work was the production and investigation of heat-resistant ceramic pigments with mullite structure by using industrial waste vanadium catalyst. 


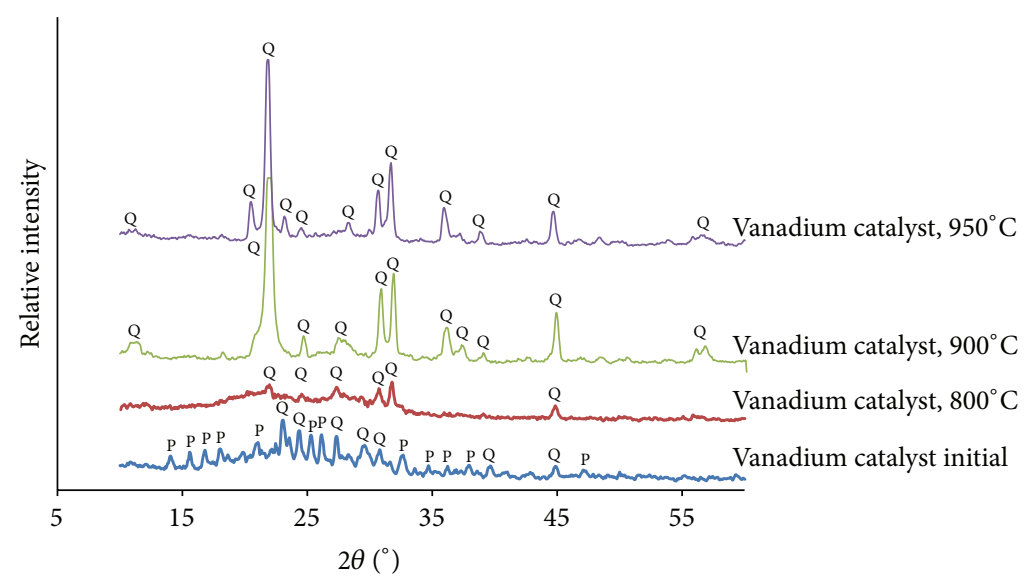

FIGURE 1: The XRD data of vanadium catalysts initial and calcinated at the temperatures 800,900 , and $950^{\circ} \mathrm{C}$. Q quartz: $\mathrm{P}$ and potassium vanadium sulfate.

TABLE 1: Chemical composition of the waste vanadium catalyst.

\begin{tabular}{lccccc}
\hline \multirow{2}{*}{ Raw material } & \multicolumn{5}{c}{ Oxide content, wt.\% } \\
& $\mathrm{SiO}_{2}$ & $\mathrm{Al}_{2} \mathrm{O}_{3}$ & $\mathrm{~V}_{2} \mathrm{O}_{5}$ & $\mathrm{~K}_{2} \mathrm{O}$ & $\Delta m^{1}$ \\
\hline Waste vanadium catalyst & 64.90 & 5.20 & 6.20 & 9.10 & 14.60 \\
\hline
\end{tabular}

${ }^{1}$ Ignition loss, wt.\%.

\section{Materials and Methods}

2.1. Raw Materials and Formulations. The raw material used in the study was a waste vanadium catalyst (WVC), which is used for the manufacture of sulfuric acid in the plant "Nitrogen" (Kemerovo, Russia) in the work.

Raw materials for WVC are natural diatomite, vanadium oxide $\left(\mathrm{V}_{2} \mathrm{O}_{5}\right)$, potassium oxide $\left(\mathrm{K}_{2} \mathrm{O}\right)$, and sulfur oxide $\left(\mathrm{SO}_{3}\right)$ in the form of potassium vanadium sulfate $\left(\mathrm{K}_{2} \mathrm{~S}_{2} \mathrm{O}_{7} \cdot \mathrm{V}_{2} \mathrm{O}_{5}\right)$. Diatomite contains $90 \%$ of the shells of diatomite seaweed; $2-7 \%$ of quartz; the rest are feldspar, glauconite, and mica.

The chemical composition of WVC was determined by $\mathrm{X}$-ray fluorescence analysis (XRF, Philips $\mathrm{X}^{\prime} \mathrm{UNIQUE}$ II) (Table 1). Initial WVC contains significant amount of highly volatile components in the form of sulfur oxide $\mathrm{SO}_{3}$. Thus, previously WVC was treated by heating at the temperatures 900-950 $\mathrm{C}$ for one hour to apply it for ceramic pigment production. Calcination at this temperature is necessary to remove the volatile impurities of sulfur oxide; at the same time, vanadium oxide is removed too. The main product of calcination is $\mathrm{SiO}_{2}$ according the XRD data (Figure 1). The other oxides $\left(\mathrm{Al}_{2} \mathrm{O}_{3}, \mathrm{~K}_{2} \mathrm{O}\right)$ are contained in small quantities (see Table 1); so their reflexes are weak on radiographs. The major part of $\mathrm{V}_{2} \mathrm{O}_{3}$ was captured and removed along with volatile compounds during the heat treatment. The final color of pigments and dyes was not affected by $\mathrm{V}_{2} \mathrm{O}_{3}$, which has its own coloring ability.

The WVC comprised the structure-forming oxides$\mathrm{SiO}_{2}$, and $\mathrm{Al}_{2} \mathrm{O}_{3}$. Aluminum oxide $\left(\mathrm{Al}_{2} \mathrm{O}_{3}\right)$ was added to the catalyst to provide mullite structure formation. $\mathrm{Al}_{2} \mathrm{O}_{3}$ was $99.9 \%$ of purity and particle size of $20-30 \mu \mathrm{m}$.
2.2. Preparation and Characterisation of Pigments. Waste vanadium catalyst was milled up to particle size less than 20-30 microns. Aluminum oxide is included in the catalyst composition but in a small concentration (up to $5 \mathrm{wt} . \%$ ), which is not enough to form mullite. So additional alumina was added to WVC to obtain stoichiometric mullite by the following reaction:

$$
\begin{aligned}
& \left(\mathrm{SiO}_{2} ; \mathrm{Al}_{2} \mathrm{O}_{3} ; \mathrm{K}_{2} \mathrm{O}\right)+\mathrm{Al}_{2} \mathrm{O}_{3} \\
& \longrightarrow 3 \mathrm{Al}_{2} \mathrm{O}_{3} \cdot 2 \mathrm{SiO}_{2} \text { (solid solution) } \\
& \quad+\text { glass phase }\left(\mathrm{SiO}_{2} ; \mathrm{Al}_{2} \mathrm{O}_{3} ; \mathrm{K}_{2} \mathrm{O}\right)
\end{aligned}
$$

Firstly, WVC of 42 wt.\% and alumina of $58 \mathrm{wt} \% \%$ were mixed without any chromophore by dry method in a ball mill for $3 \mathrm{~h}$. This mixture was named as "check sample" (CS) and used to determine structure formation. The prepared composition mixture was sintered in corundum pots at $T_{\text {sint. }}=1100-1200^{\circ} \mathrm{C}$. The XRD analysis showed that mullitecorundum structure was formed instead of expected mullite one. This indicates that $\mathrm{Al}_{2} \mathrm{O}_{3}$ has not completely reacted and remained in the reaction products. But this fact does not affect the properties of the obtained pigments, in particular, on heat resistance. The mixtures on the base of $\mathrm{WVC} / \mathrm{Al}_{2} \mathrm{O}_{3}$ in proportions, considering the content additive, were made to obtain pigments (Table 2). Water-soluble salts (nitrate or sulfate) of the d-elements: $\mathrm{Ni}^{2+}, \mathrm{Co}^{2+}, \mathrm{Fe}^{3+}$, and $\mathrm{Cr}^{3+}$ were injected in the mixture as chromophores. When heated, the decomposition of salts up to oxides and the removal of volatile residues take place. The chromophores have a high diffusion capacity in this state and, as a result, provide a stable bright color of pigments. The prepared mixture was subjected to wet grinding in a ball mill for $1 \mathrm{~h}$, dried at $T=120^{\circ} \mathrm{C}$ for $2 \mathrm{~h}$, and sintered in corundum pots at $T_{\text {sint. }}=1100-1200^{\circ} \mathrm{C}$. Prepared materials were being grinded in a ball mill for $24 \mathrm{~h}$. The obtained samples were ground to a residue on the sieve no. 0063 (the size of the cell is $63 \mu \mathrm{m}$ or $10.000 \mathrm{hole} / \mathrm{sm}^{2}$ ) no more than $0.2 \mathrm{wt}$. $\%$ to provide a uniform coating during further pigments application. 
TABLE 2: The initial compositions to obtain mullite pigments.

\begin{tabular}{|c|c|c|c|c|c|c|}
\hline \multirow{2}{*}{ Sample number } & \multicolumn{6}{|c|}{ The content of main components, wt.\% } \\
\hline & WVC & $\mathrm{Al}_{2} \mathrm{O}_{3}$ & $\mathrm{CoO}$ & $\mathrm{NiO}$ & $\mathrm{Cr}_{2} \mathrm{O}_{3}$ & $\mathrm{Fe}_{2} \mathrm{O}_{3}$ \\
\hline $\mathrm{CS}^{2}$ & 42 & 58 & - & - & - & - \\
\hline M1 & 38 & 57 & 5 & - & - & - \\
\hline M3 & 34 & 51 & 15 & - & - & - \\
\hline M4 & 38 & 57 & - & 5 & - & - \\
\hline M6 & 34 & 51 & - & 15 & - & - \\
\hline M7 & 38 & 57 & - & - & 5 & - \\
\hline M8 & 36 & 54 & - & - & 10 & - \\
\hline M9 & 38 & 54 & - & - & - & 5 \\
\hline M10 & 36 & 57 & - & - & - & 10 \\
\hline
\end{tabular}

${ }^{2}$ CS: check sample (without chromophores).

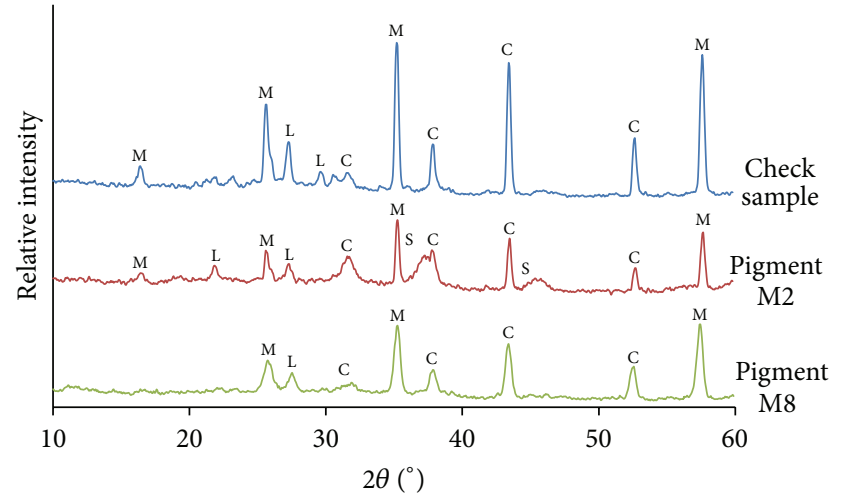

Figure 2: Radiograms of the check sample and the pigments of mullite composition, $\left(T_{\text {sint. }}=1200^{\circ} \mathrm{C}\right)$ : $\mathrm{M}$ : mullite $\left(3 \mathrm{Al}_{2} \mathrm{O}_{3} \cdot 2 \mathrm{SiO}_{2}\right)$;

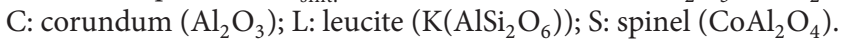

A preliminary characterisation of pigments involved the identification by X-ray diffraction (XRD-7000S Shimadzu) of the main crystalline phases formed, upon firing, and measurements of the CIE Lab colour parameters. The reflectance data in the visible region were used to obtain the three relevant parameters, $L^{*}, a^{*}$, and $b^{*}$, measuring the lightness, red/green and yellow/blue hue intensities, respectively [15]. The spectral reflection curves were measured on the spectrophotometer Cary 100 Scan to determine the color characteristics using $\mathrm{MgO}$ as a reference. The microstructure of the powders was revealed by scanning electron microscope (Philips SEM 515).

\section{Result and Discussion}

Polyphase structure was obtained at the firing of the samples without chromophores at the $T=1100^{\circ} \mathrm{C}$. It consisted of mullite $(d=0,540 ; 0,348 ; 0,255 \mathrm{~nm})$, corundum $(d=$ $0,282 ; 0,208 ; 0,173 \mathrm{~nm})$, and leucite in a small quantity $(d=0.326,0.2827 \mathrm{~nm})$ (Figure 2). SEM data confirmed the formation of mullite and corundum (Figure 3). The needle crystals were characteristic for mullite, and the plate ones for corundum.
TABLE 3: The color of the pigments and some overgraze dyes.

\begin{tabular}{lccc}
\hline \multirow{2}{*}{ Sample number } & \multicolumn{3}{c}{ The color of overglaze dyes } \\
& $1100^{\circ} \mathrm{C}^{3}$ & $1200^{\circ} \mathrm{C}^{3}$ & $850^{\circ} \mathrm{C}^{3}$ \\
\hline M1 $\left(\mathrm{Co}^{2+}\right)$ & Sky blue & Greenish blue & Sky blue \\
M3 $\left(\mathrm{Co}^{2+}\right)$ & Blue & Blue & Blue \\
M4 $\left(\mathrm{Ni}^{2+}\right)$ & Light green & Light olive & Light green \\
M6 $\left(\mathrm{Ni}^{2+}\right)$ & Turquoise & Turquoise (darker $)$ & Turquoise \\
M8 $\left(\mathrm{Cr}^{3+}\right)$ & Dark olive & Dark olive & Brownish pink \\
M9 $\left(\mathrm{Fe}^{3+}\right)$ & Light brown & Reddish brown & Brown \\
M10 $\left(\mathrm{Fe}^{3+}\right)$ & Brown & Reddish brown & Brown \\
${ }^{3}$ Sintering temperature $\left(T_{\text {sint. }}\right),{ }^{\circ} \mathrm{C}$. & &
\end{tabular}

Some amorphization of the pigment structure was observed with the increase in the firing temperature up to $1200^{\circ} \mathrm{C}$. It was associated with the presence of fusible potassium oxide $\mathrm{K}_{2} \mathrm{O}$ in the WVC (9.1 wt.\%) (see Table 1).

The intensity of the all reflections decreased when the chromophore was added (see Figure 2). This was due to the symmetry breaking and the crystal lattice distortion when the ionic chromophores incorporated into the structure and solid solutions formed [16]. It was assumed that the process of isomorphous entry of ionic-chromophores in mullite structure occurred in the position of aluminum $\mathrm{Al}^{3+}\left(r_{\mathrm{Al}}^{3+}=\right.$ $0.053 \mathrm{~nm}$ ). Based on the similarity of the ionic radii and the equality of the charges, the process was more active with the participation of $\mathrm{Cr}^{3+}\left(r_{\mathrm{Cr}}^{3+}=0.063 \mathrm{~nm}\right)$ and $\mathrm{Fe}^{3+}$ $\left(r_{\mathrm{Fe}}^{3+}=0.064 \mathrm{~nm}\right)$ ions, than at the presence of the $\mathrm{Co}^{2+}$ $\left(r_{\mathrm{Co}}^{2+}=0.072 \mathrm{~nm}\right)$ and $\mathrm{Ni}^{2+}\left(r_{\mathrm{Ni}}^{2+}=0.069 \mathrm{~nm}\right)$ ones. Nickel, chromium, and iron ions were embedded in the structure up to the concentration of the corresponding oxide $10 \mathrm{wt} . \%$ at $T_{\text {sint. }}=1200^{\circ} \mathrm{C}$. The oxides were not identified in a free form according to the result of XRD analysis (see Figure 2). It is known that the maximum solubility of $\mathrm{Fe}_{2} \mathrm{O}_{3}$ in mullite at $T_{\text {sint. }}=1600^{\circ} \mathrm{C}$ is $12 \mathrm{wt} . \%, \mathrm{Cr}_{2} \mathrm{O}_{3}-10 \mathrm{wt} . \%$ [13].

The spinel $\mathrm{CoAl}_{2} \mathrm{O}_{4}(d=0.242 ; 0.200 \mathrm{~nm})$ formed in the cobalt pigments. As a result, the pigments were colored in bright blue tones due to the tetrahedral coordination of the ion $\mathrm{Co}^{2+}$ in the spinel structure. The tone of the cobaltcontaining pigments might be changed from sky blue to 
TABLE 4: Color characteristics of the obtained ceramic pigments and dyes $\left(T_{\text {sint. }}=1200^{\circ} \mathrm{C}\right)$.

\begin{tabular}{|c|c|c|c|c|c|c|}
\hline \multirow{2}{*}{ Sample number } & \multicolumn{3}{|c|}{ Pigment colour parameters } & \multicolumn{3}{|c|}{ Dye colour parameters } \\
\hline & $L^{*}$ & $a^{*}$ & $b^{*}$ & $L^{*}$ & $a^{*}$ & $b^{*}$ \\
\hline $\mathrm{M} 1\left(\mathrm{Co}^{2+}\right)$ & 48.0 & 0.0 & -16.0 & 58.0 & 0.0 & -15.0 \\
\hline $\mathrm{M} 3\left(\mathrm{Co}^{2+}\right)$ & 38.0 & 0.0 & -19.0 & 44.0 & 0.0 & -10.0 \\
\hline $\mathrm{M} 4\left(\mathrm{Ni}^{2+}\right)$ & 53.0 & -6.0 & 6.1 & 66.0 & -1.0 & 11.0 \\
\hline $\mathrm{M} 6\left(\mathrm{Ni}^{2+}\right)$ & 46.0 & -6.0 & 4.7 & 56.0 & -4.0 & 9.4 \\
\hline $\mathrm{M} 8\left(\mathrm{Cr}^{3+}\right)$ & 44.0 & 2.4 & 2.8 & 54.0 & 10.0 & 19.0 \\
\hline $\mathrm{M} 9\left(\mathrm{Fe}^{3+}\right)$ & 47.0 & 4.3 & 9.9 & 57.0 & 11.0 & 15.0 \\
\hline $\mathrm{M} 10\left(\mathrm{Fe}^{3+}\right)$ & 38.0 & 7.6 & 7.1 & 54.0 & 5.2 & 18.0 \\
\hline
\end{tabular}

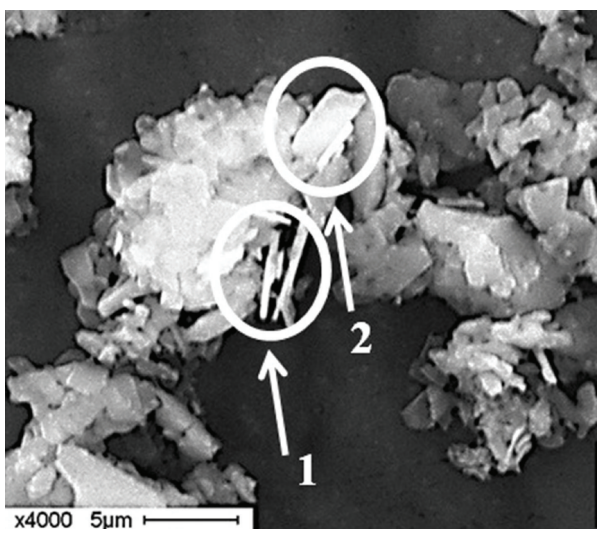

(a)

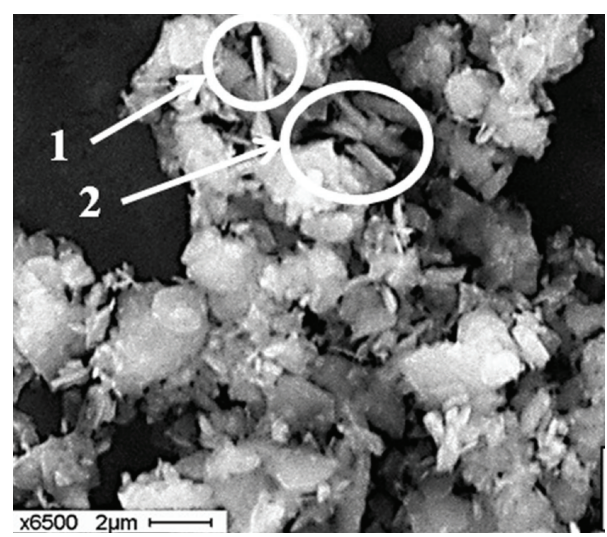

(b)

FIGURE 3: SEM images of the pigments of mullite composition: (a) check sample; (b) chromium-containing pigment. The areas on the images are $1-$ mullite, and $2-$ corundum $\left(T_{\text {sint. }}=1200^{\circ} \mathrm{C}\right)$.

blue, depending on the concentration of oxide $\mathrm{CoO}$ (Table 3 , Figure 4). Nickel oxide $\mathrm{NiO}$ gave pigments turquoise color, iron oxide $\mathrm{Fe}_{2} \mathrm{O}_{3}$-reddish brown one. The coloration of the chromium-containing pigments varied from brownish pink (5 wt.\% $\mathrm{Cr}_{2} \mathrm{O}_{3}$ ) to dark olive (10 wt.\% $\mathrm{Cr}_{2} \mathrm{O}_{3}$ ). It depends on the polarization value and the distance between the chromium ion and its surrounding ions. The greater the distance between the $\mathrm{Cr}^{3+}$ and $\mathrm{O}^{2-}$ the weaker the connection and the less polarization of chromium ion. The absorption maximum was shifted to the red spectrum; thus, the pigments were painted in green tones.

The pigments of mullite composition were tested as overglaze colors (see Table 3 ). They were mixed with the flux. The chemical composition of concentrated flux was as follows (wt.\%): $\mathrm{SiO}_{2}$ (16.8), $\mathrm{B}_{2} \mathrm{O}_{3}$ (15.8), $\mathrm{PbO} 6$ (7.4). The contents of the pigment and flux were in the ratio 1:3. Such dyes were deposited on glazed ceramic articles and fired at a temperature of $850^{\circ} \mathrm{C}$. Blue, turquoise, red, and brown paints were gotten. The color of the pigments did not change in overglaze dyes. Besides, the obtained pigments were added to the compositions of porcelain glazes in the amount of $5 \mathrm{wt} . \%$. The glazes were calcinated at the temperature $1200^{\circ} \mathrm{C}$. As a result, bright colored coverings were obtained. The color of all pigments in a glaze did not change too, which indicated the stability of the pigments under high temperatures in contrast to the pigments presented in [12].
The color coordinates $L^{*}, a^{*}$, and $b^{*}$ (Table 4 ), which characterize the color properties of the pigments, were calculated using the spectral reflectance curves (Figure 5). For example, cobalt pigments had a higher color saturation, which was confirmed by high values of $\mathrm{b} *$ in the blue spectral region of the system CIE $L^{*}, a^{*}$, and $b^{*}$ [15].

\section{Conclusion}

The ceramic pigments were produced using technogenic silica-containing raw material-waste vanadium catalyst in the work. Corundum phase along with the predominant mullite is identified in the composition of the obtained pigments and dyes. The ions of nickel, chromium, and iron are embedded in the structure up to the concentration of the corresponding oxide $10 \mathrm{wt} . \%$; in this case, the oxide is not identified in a free form on XRD pattern. The spinel $\mathrm{CoAl}_{2} \mathrm{O}_{4}$ forms in the cobalt-containing pigments. Cobalt pigments are characterized by the highest color saturation. The developed pigments keep a firing temperature up to $1200^{\circ} \mathrm{C}$.

The research results show that the usage of vanadium catalyst is promising and economically expedient because the pigments synthesized on its basis are not inferior industrial pigments by color properties and heat resistance, and they exceed the pigments described in [9-12]. The pigments obtained in this work can be recommended for underglaze 


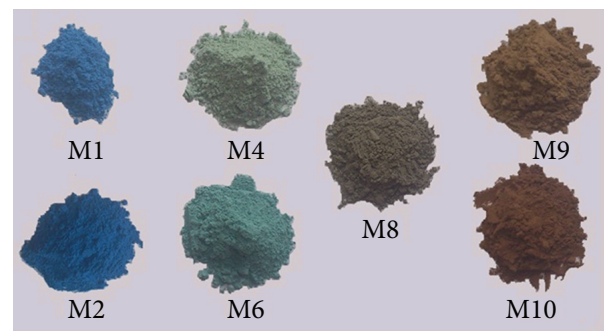

(a)

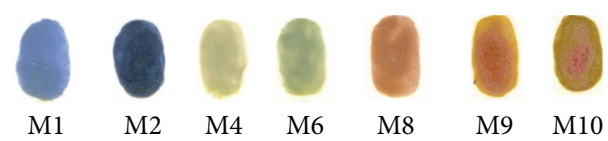

(b)

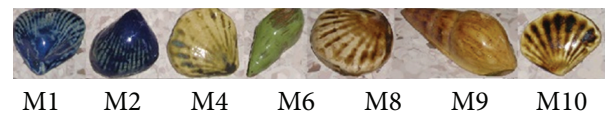

(c)

FIGURE 4: The color of the obtained pigments (a), overglaze dyes (b) and glazes (c).

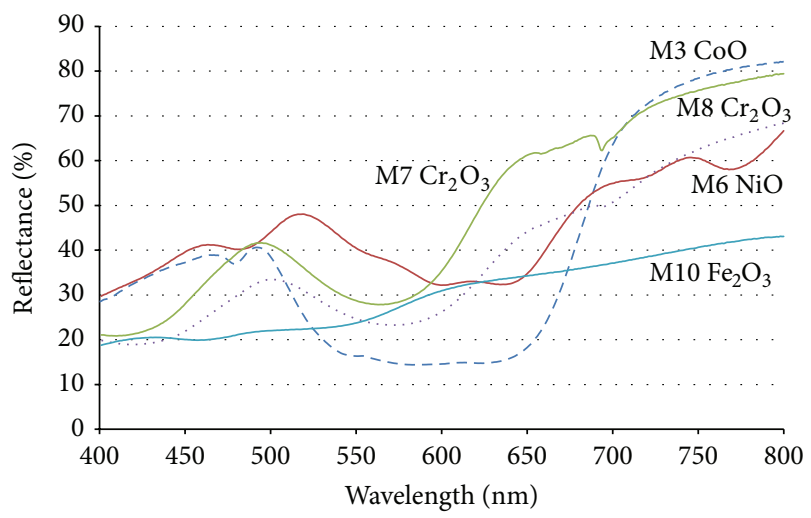

FIGURE 5: Spectral reflectance curves of the obtained pigments $\left(T_{\text {sint. }}\right.$ $=1200^{\circ} \mathrm{C}$ ).

and overglaze ceramic dyes, colored glazes, and for coloring of building materials.

\section{Abbreviations}

XRF: X-ray fluorescence

XRD: $\quad$ X-ray diffraction

SEM: $\quad$ Scanning electron microscopy

WVC: Waste vanadium catalyst

$T_{\text {sint. }}$ : $\quad$ Sintering temperature, ${ }^{\circ} \mathrm{C}$

CIE Lab: Commission Internationale

I'Eclairage-international commission on illumination of the standard colorimetric coordinates $L^{*}, a^{*}$, and $b^{*}$.

\section{Acknowledgments}

The work was supported by the Ministry of Education and Science of Russian Federation. The state task is "Science" no. 3.3055.2011.

\section{References}

[1] Y. Marinova, J. M. Hohemberger, E. Cordoncillo, P. Escribano, and J. B. Carda, "Study of solid solutions, with perovskite structure, for application in the field of the ceramic pigments," Journal of the European Ceramic Society, vol. 23, no. 2, pp. 213220, 2003.

[2] F. Andreola, L. Barbieri, and F. Bondioli, "Agricultural waste in the synthesis of coral ceramic pigment," Dyes and Pigments, vol. 94, no. 2, pp. 207-211, 2012.

[3] R. I. Lazău, C. Păcurariu, D. Becherescu, and R. Ianoş, "Ceramic pigments with chromium content from leather wastes," Journal of the European Ceramic Society, vol. 27, no. 2-3, pp. 1899-1903, 2007.

[4] E. Ozel, S. Turan, S. Çoruh, and N. O. Ergun, "Production of brown and black pigments by using flotation waste from copper slag," Waste Management and Research, vol. 24, no. 2, pp. 125133, 2006.

[5] F. Bondioli, L. Barbieri, and T. Manfredini, "Grey ceramic pigment ( $\mathrm{Fe}, \mathrm{Zn}) \mathrm{Cr}_{2} \mathrm{O}_{4}$ obtained from industrial fly-ash," Tile \& Brick International, vol. 16, no. 4, pp. 246-248, 2000.

[6] V. Gomes, A. P. N. de Oliveira, and J. A. Labrincha, "Ceramic pigment based on mullite structure obtained from Al-sludge containing formulations," The American Ceramic Society Bulletin, vol. 84, pp. 9501-9504, 2005.

[7] M. J. Ribeiro, D. U. Tulyaganov, J. A. Labrincha, and J. M. F. Ferreira, "Production of Al-rich sludge-containing ceramic bodies by different shaping techniques," Journal of Materials Processing Technology, vol. 148, no. 1, pp. 139-146, 2004.

[8] G. Costa, M. J. Ribeiro, T. Trindade, and J. A. Labrincha, "Development of waste-based ceramic pigments," Boletin de la Sociedad Espanola de Ceramica y Vidrio, vol. 46, no. 1, pp. 7-13, 2007.

[9] G. Costa, V. P. Della, M. J. Ribeiro, A. P. N. Oliveira, G. Monrós, and J. A. Labrincha, "Synthesis of black ceramic pigments from secondary raw materials," Dyes and Pigments, vol. 77, no. 1, pp. 137-144, 2008.

[10] G. Costa, M. J. Ribeiro, J. A. Labrincha, M. Dondi, F. Matteucci, and G. Cruciani, "Malayaite ceramic pigments prepared with galvanic sludge," Dyes and Pigments, vol. 78, no. 2, pp. 157-164, 2008.

[11] M. B. Sedel'nikova and V. M. Pogrebenkov, "Production of ceramic pigments with wollastonite and diopside structures using nepheline sludge," Glass and Ceramics, vol. 64, no. 9-10, pp. 363-365, 2007.

[12] M. B. Sedel'nikova, V. M. Pogrebenkov, V. V. Gorbatenko, and E. Y. Kautsman, "Ceramic pigments for construction ceramics," Glass and Ceramics, vol. 66, no. 9-10, pp. 305-309, 2009.

[13] M. K. Murthy and F. A. Hummel, "X-ray study of the solid solution of $\mathrm{TiO}, \mathrm{Fe}_{2} \mathrm{O}_{3}$, and $\mathrm{G}, \mathrm{O}_{3}$ in mullite $\left(3 \mathrm{Al}_{2} \mathrm{O}_{3} \mathrm{a} 2 \mathrm{SiO}_{2}\right)$," Journal of the American Ceramic Society, vol. 43, no. 5, pp. 267273, 1960.

[14] S. Kurajica, E. Tkalcec, and J. Schmauch, "CoAl $\mathrm{O}_{4}$-mullite composites prepared by sol-gel processes," Journal of the European Ceramic Society, vol. 27, no. 2-3, pp. 951-958, 2007. 
[15] R. Tilley, Ed., Colour and the Optical Properties of Materials, John Wiley \& Sons, London, UK, 2000.

[16] Encyclopedia of Spectroscopy and Spectrometry, 2nd edition, 1999. 

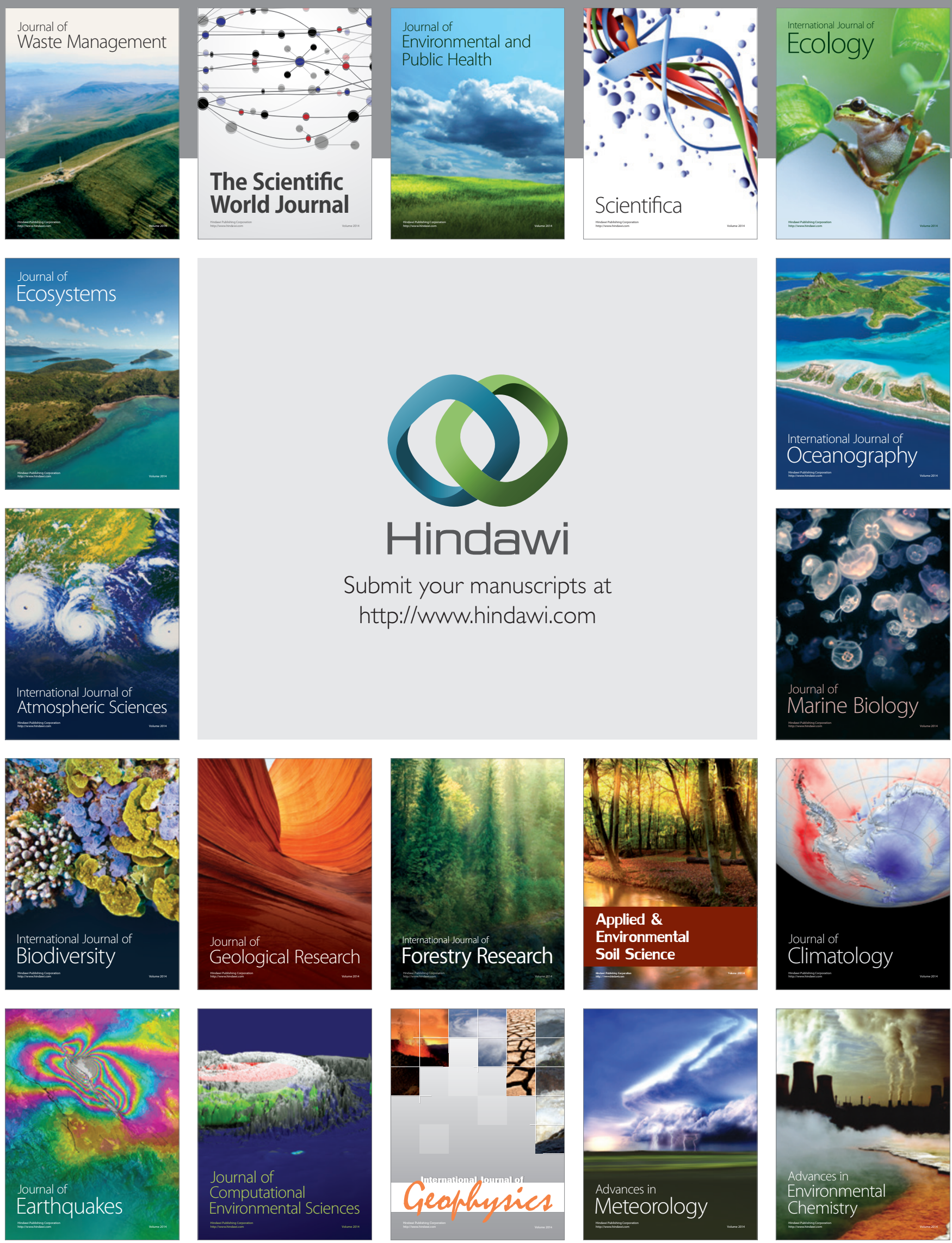